\title{
Effect 1 Vs. 1 Continous Game Against Learning Outcomes Dribbling And Controlling in Football
}

\author{
$1^{\text {st }}$ Mochamad Ridwan \\ Sport Education \\ Universitas Negeri Surabaya \\ Surabaya, Indonesia \\ mochamadridwan@unsa.ac.id
}

\author{
$2^{\text {nd }}$ Gatot Darmawan \\ Sport Education \\ Universitas Negeri Surabaya \\ Surabaya, Indonesia \\ gatotdarmawan@unesa.ac.id
}

\author{
$3^{\text {rd }}$ Frisillia Adiyta Mukti \\ Sport Education \\ Universitas Negeri Surabaya \\ Surabaya, Indonesia \\ frisilillaadityam@gmail.com
}

\begin{abstract}
Vs. 1 continuous is a game model in football with a one-on-one player, the first player to dribbling and control the ball and the second player as the opponent who becomes the shadow to seize control of the ball from the first player. The purpose of this study is to find information from existing problems, to 1). Know the effect of game 1 vs. 1 continuous to dribbling learning outcomes. 2). know the magnitude of game influence 1 vs. 1 continuous to the dribbling learning outcomes. The type of research used is quasi-experimental research with quantitative approach. The result of this research is t-test significant value on $t$ count $(0.00)<t$ table $(0.05)$ means Ha is acceptable and there is a significant influence of application of 1 vs. 1 continuous game to dribbling learning outcomes. The amount of percentage improvement is on the learning result of dribbling equal to $10.65 \%$ and on the result of a study of controlling equal to $6.02 \%$.
\end{abstract}

Keywords : small side games, dribbling, controlling, learning outcomes

\section{INTRODUCTION}

The quality of a country depends on the education taken by the community in life. Every human being is entitled to get education from various levels, especially school education. Primary to senior high school level there are subjects of physical education. "Physical education is the process of education through physical activity, games or sports selected to achieve educational goals [9]. Physical education is an educational process that gives priority to physical activity that is fun and healthy for learners. A good physical education teacher must understand the topic to be conveyed to the students, and it is also important to develop a lesson plan so that the topic is not out of the discussion and in accordance with the learning objectives. Learning model is a way for teachers to organize teaching and learning activities to run in accordance with the expected goals. According to [4] "learning model is a form of activity that describes the teaching and learning activities from beginning to end are presented in a typical by the teacher." In order for the topic to be delivered teachers can be delivered to the maximum and can be received well by students, the teacher should be able to apply the learning model that can improve student learning outcomes. Student learning outcomes are said to be good if one indicator of the learning model applied by teachers can be accepted by students. "In the learning process students follow a series of teaching and learning process to get the value obtained from the learning process. learning outcomes during the learning process. Football is a sport game that requires teamwork from all aspects to the expected goal can be achieved. To achieve a good teamwork requires players who can master a variety of basic techniques and skills to play soccer, so it can play the ball in all positions and situations quickly, precisely, and carefully means not to waste energy and time. This is in accordance with the opinion expressed by [2] "because working in teams and thereby engaging an environment and context closer to real life increases students critical thinking skills and supports their ability to put theory into practice. In a group must have one goal that produces an opportunity to achieve a goal. This is in accordance with the opinions expressed by Vilar, Luis, et al [13] "Successful performance in team sports like soccer is influenced by the ability of players to identify opportunities for actions from their spatial temporal relationships with other players (both teammates and opponents) and key task constraints (such as the location of the sidelines, goal and ball)." By applying the game model is expected to improve student learning outcomes, especially dribbling and controlling topics. Dribbling is one of the techniques of playing in football. Football is often included in physical education learning because soccer is a simple and easy game to play by students, in the sport there are many elements of character education contained in it including student co-operation. Football is one of the mediators to educate in order to become an intelligent, skilled, honest, and sportsman. At football matches, it can be seen the field stars show dribbling techniques used to pass the opponent and prepare the space to easily pass the ball to a friend. Basically dribbling is kicking discontinuously or slowly, therefore the foot used in dribbling equals the foot used to kick the ball. Dribbling aims, among others, to approach the distance to the target, through the opponent, and inhibit the game. According to [6] "the teacher is a component in teaching that plays an important and important role, because the success of the teaching and learning process is determined by the teacher's teaching model." One of 64 game models in football that leads to sub dribbling topic and controlling class 
$\mathrm{X}$ is 1 Vs 1 continuous. Controlling / controlling the ball is a technique that must be mastered by every football player. According [3] explains bawhwa "techniques in receiving the ball there are two kinds of balls that are directly stopped (stopping) and receive the ball in the sense of controlling the ball (controling). Basically controlling is done so that players easily control the ball so it is not easy to seize the opponent. Controlling is divided into ie when the ball is flat (rolling over the ground) and at the moment the ball bounces. In learning football sub-meteri controlling on class $\mathrm{X}$ is divided into three namely using the inner legs, using the outer legs and soles of the feet.

The purpose of the learning process is an increase in student learning outcomes. According [10] defines that "learning outcomes in students is a change of behavior as a result of the learning process that includes cognitive, psychomotor and affective learning outcomes." Learning outcomes are a result of judgment obtained by students during the learning process. With the results of learning can also be used as an evaluation topic for teachers. How to measure student learning outcomes is to provide tests for students. To find out and measure the learning outcomes that students get during the learning process, the teacher gives the test. According to [5] "the test is a systematic procedure created in the form of tasks standardized and given to individuals or groups to be worked on, answered, or responded to, in written form, oral or deed."

The game is not only needed in the age of the children, but the game is also needed during adolescence because with the game besides making fun also can strengthen solidarity and sensitivity to each other. With the game can increase the motivation of students and can build positive ideas. The same is also stated by [1] "Games provide a natural motivation," the game provides a natural motivation, is the right part in teaching the strategy, and the many benefits that can be used that is to help build a concept of thinking. So the game is a fun activity and as a means of socializing with the surrounding environment and can increase motivation and foster positive values such as cooperation, responsibility, honest and sportsmanship. In learning the students are expected to practice what is directed by the teacher, so the problems that arise can be minimized. There is no possibility that any learning gets difficulties in the learning process. Therefore, teachers should have the ability to use learning models that are appropriate to the conditions in the school. The model can guarantee flexibility to enable a person who uses a particular model to make adjustments to the situation or condition better. So the researchers tried to find a suitable model for learners, from some learning models used in PJOK including small side games. The 1 Vs 1 continuous game model is one of the Small Sided Soccer Games (SSG) game models prioritizing game variations. According to [8] "SSG has the characteristics defined by factors that offer multiple possibilities of variation. Several studies have analyzed the effect of modifying the number of players, pitch size, exercise duration, coach encouragement, rule changes, ball contacts and different periods of play on the physiological demands of soccer. SSG has characteristics and factors that offer many variations. Several studies have analyzed the effect of modification of the number of players, field size, duration of training, support from coaches, regulatory changes, contact with balls and different types of games about physiological soccer game

Characteristics of the SSG game is a football game model that in the implementation can adjust to existing conditions in the field including the number of players, rules of the game, field size, game duration, contact with the ball, and changes in different types of games. The purpose of this study is to find information from the problems that exist in the formulation of the above problems. 1). To know the effect of $1 \mathrm{Vs} 1$ continious game on dribbling learning outcomes and controlling soccer on students of class X IPA 1 Senior High School 16 Surabaya. 2). To know the magnitude of game influence 1 Vs 1 continuous to learning result dribbling and controlling soccer in student class X IPA 1 in Senior High School 16 Surabaya.

\section{MATERIALS AND METHODS}

In this research type of research used is quasi experimental research with quantitative approach. This quasi-experimental research is a type of experimental research whose requirements are not satisfied in pure experimental research, such as controlling variables, control groups, treatment or manipulation of activities and test results. Among the four requirements, the study did not use a control group so it was called pre experiment. According to [11] "called quasi experiments because there is no characteristic equation (random) and no control of variables." The design of this study was by using One Group Pretest - Posstest Design because there was only one sample group and did not use the control group. According [12] explains that in the design model of this study, the group was not randomly or coupled, nor was there a comparison group, but was given preliminary and final tests in addition to the treatment. In a study there were populations and samples. "Sampling is the process of selecting a sufficient number of elements from the population, so that 1 out of 10 classes of class $X$ with the number of each class between 30-40 research students on the sample and an understanding of the nature or characteristics will allow us to generalize the nature or characteristics is on the population element "[7]. In this research the sampling technique using simple random sampling. In conducting instrument research is needed for researchers to determine the success of treatment given to the subject of research. According [10] explains that "The research instrument is a tool to measure tests in a study. The research instrument is a tool used to measure both natural and social phenomena being observed. "In this study the instrument used is a zig-zag test.

\section{RESULT AND DISCUSSIONS}

Analysis of the results of this study will be described with descriptive results of the results of hypothesis testing. Descriptive data to be presented in the form of data from learning result of Physical Education dribbling topic and 
controlling of soccer before and after given game 1 Vs 1 continuous at student of class X IPA 1 Senior High School 16 Surabaya obtained from pre- test and post-test experimental group. As for the sample of research that is class X IPA 1 with the number of students as much as 36 students, but at the time of taking data of students who follow the pre-test, treatment 1 , treatment 2 and post-test only amounted to 24 students. In the description of this data will discuss the average value, standard deviation, variant, the highest value and the lowest value of the average pre-test and post-test treatment group about the effect of $1 \mathrm{Vs} 1$ continuous game on learning outcomes dribbling and controlling soccer. Based on the results of the above data it can be seen the average value of pre-test dribbling is 70.40 with standard deviation of 3.11 variant of 9.68, the lowest value of 66.70 and the highest value of 75.00. While in the post-test data the average value is 77.90 with a standard deviation of 2.50 , a variant of 6.23 , the lowest value of 72.90 and the highest value of 81.20 . In the pre-test controlling the average score was 73.38 , with the standard deviation of 2.86, the variance of 8.16 , the lowest score of 69.00 , the highest score of 78 . While in post-test controlling the average value was 77.80 , with a standard deviation of 2.84 , a variance of 6.23 , the lowest score of 72 , the highest score of 83 . the difference between the pre-test and post-test dribbling for the mean is 7.5 , the standard deviation difference between the pre-test and the post-test is 0.61, the variance difference between the pre- and post-test values of 3.45, the lowest difference between the pre-test and the post-test. So from the result of the data can be seen big increase between pre-test and post-test class X IPA 1 that is $=10,65 \%$. While on controlling result the difference between pre-test and post-test average value is 4.42 , deviation standard difference value between pre-test and post-test is 0,02, varian difference value between pre-test and post- test of 1.93, the minimum difference between the pre-test and the post-test is 3 , and the maximum difference between the pre-test and the post-test of 5. So from that result can be seen the increase between pre-test and post- test that is $6.02 \%$.

First pre-test research process consisted of 3 aspects of the test such as affective using attitude assessment, cognitive observation by answering 4 items essay, and psychomotor dribbling with zig-zag test and controlling with judgment expert. Pre-test is done during teaching and learning activities that is $3 \times 45$ minutes. In the process of implementing all three test items, students are accompanied by researchers and students explained about the rules and how to perform the three test items. In the implementation of psychomotor tests students follow the zig-zag test for dribbling and judgment expert skills for controlling skills look enthusiastic but still difficult to do controlling and dribbling because students have not been able to master the motion of the ball. At the second meeting, the students who followed the treatment of 33 students with 2 sick students and 1 without information. This second meeting uses 3 games of 1 Vs 1 continuous 1 Vs 1 continuous 1-goals, 1 Vs 1 continuous 2-goals and $1 \mathrm{Vs} 1$ continuous 4-goals which each game is held for 25 minutes and divided into 2 small groups in every game. With the division of the group is expected to facilitate researchers to supervise the course of the game. Overall the students still look confused in the game because previously never had a model of group competition game played individually is one on one person..

\section{CONCLUSION}

This discussion will discuss the declaration of the effect of $1 \mathrm{Vs} 1$ continuous game on the learning outcomes of dribbling and controlling in soccer in students of class X IPA 1 in Senior High School 16 Surabaya. In this study, researchers apply the learning model in the form of the game is expected to improve student learning outcomes, especially on soccer learning topics that is dribbling and controlling that is by applying the game $1 \mathrm{Vs} 1$ continuous. In the research process, the first meeting conducted pre-test consisting of 3 aspects of the test such as affective using attitude assessment, cognitive observation by answering 4 items essay, and psychomotor dribbling with zig-zag test and controlling with judgment expert. Pre-test is done during teaching and learning activities that is $3 \times 45$ minutes. In the process of implementing all three test items, students are accompanied by researchers and students explained about the rules and how to perform the three test items. In the implementation of psychomotor tests students follow the zig-zag test for dribbling and judgment expert skills for controlling skills look enthusiastic but still difficult to do controlling and dribbling because students have not been able to master the motion of the ball.

Students are given treatment by using 3 kinds of 1 Vs 1 continuous game that is $1 \mathrm{Vs} 1$ disguiuse (spotters), $1 \mathrm{Vs} 1$ lose defender, and $1 \mathrm{Vs} 1$ random. In this second treatment the game model level is more difficult than the previous game model. Just like the second meeting, each game is held for 25 minutes and is divided into 2 small groups in each game. Differences seen in the third treatment, students look enthusiastic and more active in the game activity because it can mempamahi rules and how to play games. Differences are seen in the post-test with pre-test performed earlier. In psychomotor test zig-zag test for dribbling skill test and judgment expert for test of student's controlling skill, there is a change in motion control. In the pre-test students are still difficult to control the movement of the ball and the body is still less relaxed, but in this post-test students are accustomed to control the motion of the ball and the body can relax.

\section{REFERENCES}

[1] Carrol, Marganet Kelly. 2011, "Fun and Games in Higher Education," vol. 40, no. 1. Taken from: http://castle.eiu.edu. /ejournal/Spring_2011/Fun_and_games.pdf.

[2] Colak, E. 2015, "The Effect Of Cooperative Learning On The Learning Approaches Of Students With Different Learning Styles," Eurasian journal of Educational Research, 59,1734.http://dx.doiorg/10.14689/ejer.2015.59.2

[3] Kemdikbud. 2016, "Physical Education, Sport and Health Class X. Jakarta: Curriculum and Book Center," Balitbang, Kemdikbud.

[4] Komalasari. 2010, "Contextual Learning," Bandung: PT Refika Aditama.

[5] Matondang, Zulkifli. 2009, "Validity and Reliability of a Research Instrument," Tabularasa Journal PPS UNIMED vol. 6, no. 1 pp. 8. 
Taken

http://digilib.unimed ac.id/705/1/Validitas\%20dan\%20reliabilita atu\%20instrumen\%20penelitian.pdf.

[6] Nassaruddin. 2015, "Improving the Results of Science Learning With Cooperative Learning Model Type STAD At Students Class IV SDN 10/73 Arrallae Kecamatan Kahu Kabupaten Bone. Journal of Educational Publications," vol. 5, no 3 halaman 247. Taken from: http://ojs.unm.ac.id/index.php /pubpend/ article/view/1684.

[7] Noor, Juliansyah. 2011, "Research methodology: Skripsi, Tesis, Disertasi, dan Karya Ilmiah,” Jakarta: Kencana Predana Media Group.

[8] Rodenaz, Joaquin Gonzales, etc. 2015, "Effect of the Game Design, the Goal Type and the Number of Players on Intensity of Play in SmallSided Soccer Games in Youth Elite Players," vol. 49 pp. 229-235. Taken from: https://www.ncbi .nlm.nih.gov/pmc/articles/PMC4723172/ .
[9] Rosdiani. Dini. 2013, "Planning Learning In Physical Education And Health,” Bandung: Alfabeta.

[10] Sugiyono. 2013, "Quantitative, Qualitative, and Combinative Methods (Mixed Methods)," Bandung: Alfabeta.

[11] Sudjana, Nana. 2009, “Assessment of Teaching and Learning Outcomes," Bandung: Remaja Rosdakarya.

[12] Sukmadinata, Nana Syaodih. 2010, "Educational Research Methods," Bandung: PT Remaja Rosdakarya.

[13] Vilar, Luis, Esteves, Pedro T., Travassos, Bruno, Passos, Pedro, Lago-Penas, Carlos and Davids, Keith. 2014. Varying numbers of players in small-sided soccer games modifies action opportunities during training., 9 (5), 1007-1018. 